\title{
Lenovo Acquires IBM's x86 Low-end Server Business
}

\author{
Article history: \\ Received: 26 April 2015 \\ Sent for revision: 4 May 2015 \\ Received in revised form: 16 August 2015 \\ Accepted: 26 August 2015 \\ Available online:
}

\begin{abstract}
This paper presents an analysis of the key events, impacts and issues of Lenovo buying IBM's x86 low-end server business. The analysis include (i) approval of the deal by regulatory bodies in the United States, Canada, India and China, (ii) security concerns of US government departments, (iii) pricing of the deals, (iv) possible impact on IBM in future, and ( $v$ ) possibilities of Lenovo making it repeat of acquiring ThinkPad business of IBM. The paper presents analysis of qualitative and time series quantitative data. The qualitative data are mainly consists of different events before and after the acquisition of x86 server IBM business by Lenovo. The quantitative data are analyzed with respect to growth parameters of overall server business and Lenovo server business. Research paper also attempts to find out answer to specific 9 research questions with respect to impact on eco-systems of IBM and Lenovo. Based on analysis, it is inferred that IBM is not able to manage its traditional \& well accepted products business in the face of fierce competition \& low demand but Lenovo will manage. The deal was a financial necessity for IBM and strategic expansion in to new markets strategy for Lenovo.
\end{abstract}

Keywords: x86 server, ThinkPad, IBM, Lenovo, cloud technologies

\section{Lenovo kupio jedinicu za proizvodnju x86 low-end servera kompanije IBM}

Apstrakt: Ovaj rad predstavlja analizu ključnih događaja, uticaja i pitanja u vez ilBM-ove jedinice za proizvodnju x86 low-end server koju je kupio Lenovo.

\footnotetext{
${ }^{1}$ Management Development Institute, India, knpsingh@mdi.ac.in 
Analiza obuhvata (i) odobrenje postignutog dogovora od strane regulatornih tela SAD-a, Kanade, Indije i Kine, (ii) zabrinutost ministarstava SAD-a za bezbednost, (iii) cene postignutog dogovora, (iv) mogući uticaj na IBM u budućnosti, $i$ (v) mogućnosti da Lenovo ponovi uspeh u kupovini ThinkPad poslovanja IBM-a. Rad predstavlja analizu kvalitativnih podataka i vremenskih serija kvantitativnih podataka. Kvalitativni podaci se uglavnom sastoje od različitih događaja pre i posle kupovine jedinice za proizvodnju x86 servera IBM-a. Kvantitativni podaci su analizirani u odnosu na parameter rasta ukupnog serverskog poslovanja i serverskog poslovanja firme Lenovo. Istraživački rad takođe pokušava da sazna odgovor na 9 istraživačkih pitanja $u$ vezi sa uticajem na eko-sisteme firmil BM i Lenovo. Analiza dovodi do zaključka da IBM nije u stanju da upravlja svojim tradicionalnim i dobro prihvaćenim proizvodima nasuprot žestokoj konkurenciji i slaboj potražnji, ali će Lenovo ipak uspeti u tome. Postignut dogovor je bio finansijska potreba za IBM i strateško proširenje na novatržišta za Lenovo.

Ključnereči: x86 server, ThinkPad, IBM, Lenovo, tehnologije "klauda"

\section{Introduction}

Lenovo, US\$ 47 billion as on 20.02.15 (US\$ 30 Billion on 18.09.12) personal technology company and the world's largest PC vendor will be completing purchase of IBM's X86 low-end server unit and Google's Motorola Mobility unit by the end of 2015 according to Osborne (2014b). Its line of product includes smart phones, tablets, laptops, desktops, workstations, servers, monitors, and accessories. One of the most important factors for growth of Lenovo is its strategy to grow both organically (process and product innovation) and inorganically.

Continuing its decade old strategy, Lenovo acquired x86 server unit of IBM. IBM was losing as much as US\$ 1.5 billion a year from its $x 86$ server business. Lenovo had purchased $x 86$ server unit for US $\$ 2.3$ billion after lots of hiccups with respect to value of the deal which was placed by IBM as high as US $\$ 6$ billion (Annie (2013)). Lenovo acquired Google's Motorola Mobility for US\$2.9 billion as part of its same strategy. IBM low-end server business deal by Lenovo for $\$ 2.3$ billion is China's biggest technology deal. This is also the second acquisition by Lenovo of IBM business. Lenovo has bought IBM's money-losing ThinkPad business for \$1.75 billion during the year 2004 .

The $x 86$ server deal includes IBM's System $x$, BladeCenter and Flex System blade servers and switches, x86-based Flex integrated systems, NeXtScale and iDataPlex servers and related software, blade networking and maintenance operations of business ((Kass (2014), Thompson (2014)). Lenovo gets all of the development, sales and marketing, finance, legal, 
integrated supply chain, operations, IT, manufacturing, and service and support (maintenance) operations associated with the above mentioned assets (Laura (2014)). As part of the deal, Lenovo will inherit seven server manufacturing sites from IBM. These sites are in Beijing, Shanghai, Yokohama, Raleigh, Silicon Valley, Taipei and Brazil. It will make Lenovo $3^{\text {rd }}$ largest player in world market of $\times 86$ servers which is caped at US\$ 42 billion. According to Laura (2014), other provisions of the deal include "(i) IBM will retain its enterprise systems portfolio, including System z mainframes, Power Systems, Storage Systems and Power-based Flex servers, as well as the PureApplication, PureData and SAP Hana appliances; (ii) IBM and Lenovo will enter into a broad-based strategic collaboration; (iii) Lenovo will become IBM's preferred supplier of x86 server technology; (iv) Lenovo will license, manufacture and resell IBM Storwize and tape storage technologies, the General Parallel File System, the SmartCloud Entry, elements of the x86 system software portfolios, and the Platform Computing portfolio; (v) Integrated systems software components will move to Lenovo; (vi) Higherlevel management tools like System Director and Flex Systems Manager will remain with IBM and be licensed by Lenovo; (vii) IBM and Lenovo will work together on patches to IBM software required by Lenovo; and (viii) Until the transaction is completed, the two companies will continue to operate independently." It means Lenovo still need to work with IBM for the repeat of possible success of ThinkPad business. The payment terms are almost same of both deals of IBM and Lenovo.

These entire events have promoted organic growth for Lenovo, created new synergies among workforce, and will contribute significantly to overall business success of Lenovo in future. The publicity of these deals is not to the level of Microsoft acquiring Nokia's mobile handset business or Verizon Wireless acquiring Vodafone's USA business (Singh (2014a, b)) because of much less size of the deals. However, two deals of IBM and Lenovo are very important and may have huge impact not only on personal information technology businesses but also on electronic industry as a whole. One of the most important impacts could be what next for Lenovo in IBM business or in any other loss making unit of big or small companies. Secondly, can Lenovo sustain the declining market segment of X86 IBM servers? Keeping in view, the importance of this deal, this paper attempts to analyze the impact of the deals on Lenovo low end server business in days to come. In addition, research paper discusses many issues cropped up during the process of acquisition such as security concerns of defense department of US government, workers strikes for better compensations from Lenovo, impact on stakeholders such as users \& channel partners, impact on Lenovo business, impact on IBM business, and impact on competitors in the same business domain starting with Lenovo growth and ending with concluding remarks. The research paper also included a section of research methodology giving details 
of the nine research questions. Subsequently, research paper presents answers to the nine research questions based on the analysis of qualitative and quantitative secondary data.

\section{Research Methodology}

Research methodology of the paper can be termed as exploratory in nature since it is based on secondary piecemeal data collected from many sources on Internet. It contains sufficient amount of historical as well as current data which is sufficient to conclude or answer research questions, therefore, methodology can be termed as exploratory cum descriptive in nature. The conclusions are drawn based on both qualitative and quantitative secondary data collected from the various resources mainly internet (websites of main stakeholders). However, findings need further examination with the availability of more data on the subject in near future. The analysis of the research paper can be termed as content analysis, event analysis, and trend analysis. Analysis attempts to generate possible answer of following nine research questions.

Research Question 1: Will Lenovo be able to repeat success of IBM's ThinkPad business deal?

Research Question 2: Will it expand Lenovo markets for its existing products as well as products of acquired unit of $x 86$ servers?

Research Question 3: Is Synergy Trap Hypothesis true in acquisition of $x 86$ server business?

Research Question 4: Will it help Lenovo to acquire more loss making units if any and do innovation in server manufacturing technology and processes?

Research Question 5: Is inorganic expansion path better for faster growth in high tech electronic industry?

Research Question 6: Will huge local market for $x 86$ servers help Lenovo to repeat the success of ThinkPad PC business acquisition?

Research Question 7: Will IBM's bottom line improve?

Research Question 8: Will it help Lenovo to take advantage of unique skills and knowledge of IBM's work force in X86 server domain?

Research Question 9: Will it convert in to a "good opportunities" to take over a corporation when it is making loss in low demand era and have potential to grow with better management or changed management skills?

Further, research analysis included many events linked to the deal. The events included in the analysis are (i) success of ThinkPad PC business acquisition, (ii) approval by regulatory agencies in China, European 
Commission, India and USA, (iii) Chinese science and technology reform, (iv) Han card technology, ( $v$ ) inorganic path of success (vi) converged infrastructure $(\mathrm{Cl})$ or pure system strategy v/s converged system strategy, (vii) cost cutting measures by management of Lenovo, (viii) solution of security concern of US Government, (ix) approval for the deal by Competition Commission of India (CCI), (x) condition put forth by GlobalFoundries (GF), (xi) buying more time by Fujitsu, (xii) non-seriousness on part of Dell Inc, (xiii) IBM announcement to spend \$1bn building up its Watson software business, (xiv) IBM announcement of spending $\$ 1.2 \mathrm{bn}$ on datacenters for cloud computing, (xv) IBM announcement to spend \$3bn on Research \& Development over the next five years to make sure processors are compatible with the demand of big data applications, (xvi) movement of stock prices, (xvii) announcement of investment in technology by many countries, etc. Analysis and discussion begin with impact of ThinkPad business on Lenovo.

\section{Lenovo Growth}

$50 \%$ of x86 servers are implemented either in Media industry or in government organization followed by telecom as mentioned in table 1 . None of the three segment of the market is going to shrink in the next 10 or more years. These segments will continue to implement $x 86$ servers. It is good for Lenovo growth and acquiring $x 86$ server businesses may fell in line with acquisition of ThinkPad business.

Table 1. Worldwide x86 market share (\%) by Industry during Q1 2013

\begin{tabular}{|l|l|l|l|l|l|l|l|l|l|l|}
\hline $\begin{array}{l}\text { Ind } \\
\text { ustr } \\
\text { y }\end{array}$ & $\begin{array}{l}\text { M } \\
\text { ed } \\
\text { ia }\end{array}$ & $\begin{array}{l}\text { Gove } \\
\text { rnme } \\
\text { nt }\end{array}$ & $\begin{array}{l}\text { Tel } \\
\text { eco } \\
\text { m }\end{array}$ & $\begin{array}{l}\text { Educ } \\
\text { ation }\end{array}$ & $\begin{array}{l}\text { Finan } \\
\text { ce }\end{array}$ & $\begin{array}{l}\text { Manuf } \\
\text { acturi } \\
\text { ng }\end{array}$ & $\begin{array}{l}\text { Serv } \\
\text { ice }\end{array}$ & $\begin{array}{l}\text { Utilit } \\
\text { ies }\end{array}$ & $\begin{array}{l}\text { Transp } \\
\text { ortation }\end{array}$ & $\begin{array}{l}\text { Oth } \\
\text { ers }\end{array}$ \\
\hline $\begin{array}{l}\text { Sha } \\
\text { re }\end{array}$ & 31 & 19 & 9 & 8 & 8 & 7 & 5 & 3 & 3 & 7 \\
\hline
\end{tabular}

Source: http://www.idc.com/getdoc.jsp?containerld=prCN24226113

As mentioned earlier growth strategy of Lenovo can be termed as organic as well inorganic. At Lenovo inorganic growth creates synergy as it works as catalyst for organic growth. The events of inorganic growth through acquisition and partnership for Lenovo are listed in the following table 2. A comparison of two acquisitions of IBM businesses by Lenovo is given in table 3 . It is evident from these facts that Lenovo has learned the art of acquisition and integration of new technologies and manpower for creating synergies by over powering resistances from different quarters. 
Singh N.P.: Lenovo Acquires IBM's x86 Low-end Server Business

Table 2. Decade of Buying- Lenovo' major corporate acquisition and partnership

\begin{tabular}{|c|c|c|}
\hline $\begin{array}{l}\text { Month/ } \\
\text { Year }\end{array}$ & Target & Transaction Valuel Payment Mode \\
\hline $\begin{array}{l}\text { December } \\
2004\end{array}$ & $\begin{array}{l}\text { IBM PC } \\
\text { Business }\end{array}$ & $\begin{array}{l}\text { US } \$ 1.75 \text { Billion [US } \$ 650 \text { Million cash + US } \$ 600 \text { Million in } \\
\text { securities +18.9\% stake in Lenovo (Spooner and Kanellos } \\
\text { (2004))]. Deal made Lenovo a global PC vendor with global } \\
\text { brand. }\end{array}$ \\
\hline $\begin{array}{l}\text { November } \\
2009\end{array}$ & $\begin{array}{l}\text { Lenovo Mobile } \\
\text { Communications }\end{array}$ & $\begin{array}{l}\text { US } \$ 200 \text { Million [US } \$ 200 \text { million in cash and Lenovo shares } \\
\text { for entire interest of Lenovo Mobile Communication } \\
\text { Technology Ltd. from a group of investors led by Hony } \\
\text { Capital, the private equity arm of Legend Holdings (News } \\
(2009) \text { )]. }\end{array}$ \\
\hline $\begin{array}{l}\text { January } \\
2011\end{array}$ & $\begin{array}{l}\text { NEC PC Joint } \\
\text { Venture }\end{array}$ & $\begin{array}{l}\text { Joint venture was formed between Lenovo (51\%) and NEC } \\
(49 \%) \text {. NEC required to hold US\$ } 175 \text { Million for } 281 \text { million } \\
\text { shares for the period of two years. Later on this condition } \\
\text { was waived off due to financial needs of NEC. NEC was } \\
\text { making loss at the time of formation of joint venture. Deal } \\
\text { made Lenovo \#1 PC vendor in Japan (News (2011), } \\
\text { Alabaster (2012)). }\end{array}$ \\
\hline July 2011 & $\begin{array}{l}\text { Germany's } \\
\text { Medion AG }\end{array}$ & $\begin{array}{l}\text { US\$ } 337.5 \text { Million [231 million Euros (US\$340 million), or } 13 \\
\text { Euros per share, to Medion's biggest shareholder } \\
\text { Brachmann for a 36.6\% stake (Yee and Soh (2011))]. On } \\
\text { March 31, 2014, Lenovo holds } 79.82 \% \text { share capital of } \\
\text { Medion AG. It is in fact } 87.54 \% \text { as per the German Security } \\
\text { Trading Act. Deal enhances brand, channel, and scaling in } \\
\text { Western Europe. } \\
\text { (http://www.medion.com/en/investor/stock_corporation/) }\end{array}$ \\
\hline $\begin{array}{l}\text { September } \\
2012\end{array}$ & $\begin{array}{l}\text { CCE, Brazil PC } \\
\text { Maker }\end{array}$ & US\$145.4 Million [Cash and Stock (Whittaker (2012a))]. \\
\hline $\begin{array}{l}\text { December } \\
2012\end{array}$ & Stoneware & To boost cloud offerings. [\$ 44 Million (Whittaker (2012b))]. \\
\hline $\begin{array}{l}\text { December } \\
2012\end{array}$ & $\mathrm{EMC}^{2} /$ lomega & $\begin{array}{l}\text { US\$ } 59 \text { Million. Partner with EMC }{ }^{2} \text { to co-brand EMC's } \\
\text { lomega line to provide network storage products for small } \\
\text { and medium businesses, remote branches, and distributed } \\
\text { enterprise scenarios as LenovoEMC [Bradley (2013))]. }\end{array}$ \\
\hline $\begin{array}{l}\text { January } \\
2013\end{array}$ & CCE & $\begin{array}{l}\text { US\$146 Million [US\$102 cash + US\$43 in Equity] CCE was } \\
\text { founded in } 1964 \text { and became largest PC maker in Brazil. } \\
\text { Lenovo buys it to establish local brand and manufacturing } \\
\text { facilities in Brazil and also to double its share in Brazil } \\
\text { market (Whittaker (2012a)). }\end{array}$ \\
\hline $\begin{array}{l}\text { January } \\
2014\end{array}$ & $\begin{array}{l}\text { IBM x86 Server } \\
\text { Business }\end{array}$ & $\begin{array}{l}\text { US\$2.10 Billion [US\$1.8 billion in cash, and US\$280 } \\
\text { million of its stock to IBM. It was less by US } \$ 200 \text { Million in } \\
\text { cash due to value of transferred inventories (Kan (2014))] }\end{array}$ \\
\hline $\begin{array}{l}\text { January } \\
2014\end{array}$ & Motorola Mobility & $\begin{array}{l}\text { US } \$ 2.91 \text { Billion [US } \$ 660 \text { million in cash+ US } \$ 750 \text { million in } \\
\text { Lenovo ordinary shares (subject to a share cap/floor) + } \\
\text { US } \$ 1.5 \text { billion in the form of a three-year promissory note + } \\
\text { cash compensation of approximately US } \$ 228 \text { million for the } \\
\text { cash and working capital held by Motorola at the time of } \\
\text { close (News }(2014 a, 2014 b) \text { ). }\end{array}$ \\
\hline
\end{tabular}


Singh N.P.: Lenovo Acquires IBM's x86 Low-end Server Business

Table 3. Comparison of Two IBM deals with Lenovo

\begin{tabular}{|c|c|c|c|}
\hline Parameters & $\begin{array}{c}\text { IBM ThinkPad PC } \\
\text { Business }\end{array}$ & $\begin{array}{c}\text { IBM's x86 Server } \\
\text { Business }\end{array}$ & Source \\
\hline Value & US \$ 1.75 Billion & US \$ 2.1 Billion & \multirow{4}{*}{$\begin{array}{c}\text { Barinka } \\
\text { (2014), } \\
\text { Spooner } \\
\text { and } \\
\text { Kanellos } \\
(2004)\end{array}$} \\
\hline Year & 2004 & 2014 & \\
\hline Payment & $\begin{array}{l}\text { US\$ } 650 \text { Million in cash + } \\
\$ 600 \text { million in securities. }\end{array}$ & $\begin{array}{l}\text { US \$1.80 Billion } \\
\text { in cash }\end{array}$ & \\
\hline Payment & $\begin{array}{l}\text { IBM will have } 18.9 \% \\
\text { stake in Lenovo \& will } \\
\text { remain Lenovo's second- } \\
\text { largest shareholder }\end{array}$ & $\begin{array}{l}\$ 280 \text { million of its } \\
\text { stock to IBM. }\end{array}$ & \\
\hline
\end{tabular}

\section{Impact of buying ThinkPad PC Business on Lenovo}

With the acquisition of ThinkPad PC Business, Lenovo will have an annual sales volume of 11.9 million units and revenue of $\$ 12$ billion. This is based on the sales data of 2003 (Spooner and Kanellos (2004)). Lenovo has roughly 19,200 employees (10,000 IBM employees+ 9,200 Lenovo employees) in 2003. Out of 10,000 employees of IBM, $40 \%$ are in China and less than $25 \%$ are in USA. As can be seen from data presented in table 4, Lenovo not only became number 1 PC makers in the world in less than a decade after acquiring IBM ThinkPad business in 2004 but retained its position during 2013 and fourth quarter of 2014. In fact all the major manufacturers of PC have grown tremendously during quarter 4 of 2014 but Lenovo had grown more than the others. Growth of Lenovo was attributed by researchers and industry experts to many factors. Major factors as mentioned in the literature are impact of the Chinese science \& technology reform, Han-card technology, link between technology-driven and market-driven strategies adopted by Lenovo, and acquiring of IBM ThinkPad PC Business. It means acquiring IBM ThinkPad business was not the sole factor for the growth of Lenovo in PC market. Further, it is repeatedly mentioned by the top management of Lenovo that cost-cutting measures for reviving IBM Corp's ThinkPad laptop unit was one of the most important factor. It is further reported by Lenovo that lessons learned in the revival process of ThinkPad business will be used in future acquisition of loss making units across the globe including Motorola mobility and IBM x86 Server (Carsten (2013)). 
Singh N.P.: Lenovo Acquires IBM's x86 Low-end Server Business

Table 4. Global PC Market Share by Units, Percent (2003-2014)

\begin{tabular}{|c|c|c|c|c|c|c|c|c|c|c|c|c|c|}
\hline Vendor & $\begin{array}{c}2003 \\
{[1]}\end{array}$ & $\begin{array}{c}2004 \\
{[2]}\end{array}$ & $\begin{array}{c}2005 \\
{[3]}\end{array}$ & $\begin{array}{c}2006 \\
{[4]}\end{array}$ & $\begin{array}{c}2007 \\
{[5]}\end{array}$ & $\begin{array}{c}2008 \\
{[6]}\end{array}$ & $\begin{array}{c}2009 \\
{[7]}\end{array}$ & $\begin{array}{c}2010 \\
{[8]}\end{array}$ & $\begin{array}{c}2011 \\
{[9]}\end{array}$ & $\begin{array}{l}2012 \\
{[10]}\end{array}$ & $\begin{array}{l}2013 \\
{[11]}\end{array}$ & $\begin{array}{c}2014 \\
{[12]}\end{array}$ & $\begin{array}{l}2014 \\
{[13]}\end{array}$ \\
\hline Dell & $\begin{array}{r}14.9 \\
(1)\end{array}$ & $\begin{array}{r}16.4 \\
\text { (1) }\end{array}$ & $\begin{array}{r}16.8 \\
\text { (1) }\end{array}$ & $\begin{array}{r}15.9 \\
\text { (1) }\end{array}$ & $\begin{array}{r}14.2 \\
(2)\end{array}$ & $\begin{array}{r}14.1 \\
(2)\end{array}$ & $\begin{array}{r}12.1 \\
\text { (3) }\end{array}$ & $\begin{array}{r}12.0 \\
(3)\end{array}$ & $\begin{array}{r}11.7 \\
(3)\end{array}$ & $\begin{array}{r}10.7 \\
(3)\end{array}$ & $\begin{array}{r}11.6 \\
(3)\end{array}$ & $\begin{array}{r}12.5 \\
\text { (3) }\end{array}$ & $\begin{array}{r}12.7 \\
\text { (3) }\end{array}$ \\
\hline HP & $\begin{array}{r}14.6 \\
(2)\end{array}$ & $\begin{array}{r}14.6 \\
(2)\end{array}$ & $\begin{array}{r}14.6 \\
(2)\end{array}$ & $\begin{array}{r}15.9 \\
(2)\end{array}$ & $\begin{array}{r}18.1 \\
(1)\end{array}$ & $\begin{array}{r}18.2 \\
(1)\end{array}$ & $\begin{array}{r}19.1 \\
(1)\end{array}$ & $\begin{array}{r}17.9 \\
(1)\end{array}$ & $\begin{array}{r}16.6 \\
(1)\end{array}$ & $\begin{array}{r}16.1 \\
(1)\end{array}$ & $\begin{array}{r}16.2 \\
(2)\end{array}$ & $\begin{array}{r}16.0 \\
(2)\end{array}$ & $\begin{array}{r}18.8 \\
(2)\end{array}$ \\
\hline IBM & $\begin{array}{l}5.3 \\
\text { (3) }\end{array}$ & - & - & - & - & - & - & - & - & - & - & - & - \\
\hline Fujitsu & $\begin{array}{l}3.7 \\
\text { (4) }\end{array}$ & $\begin{array}{l}3.8 \\
\text { (4) }\end{array}$ & - & & - & - & - & - & - & - & - & - & - \\
\hline Acer & $\begin{array}{l}2.9 \\
\text { (5) }\end{array}$ & $\begin{array}{l}3.4 \\
\text { (5) }\end{array}$ & $\begin{array}{l}4.6 \\
(4)\end{array}$ & $\begin{array}{r}7.6 \\
\text { (3) }\end{array}$ & $\begin{array}{l}9.7 \\
\text { (3) }\end{array}$ & $\begin{array}{r}10.6 \\
(3)\end{array}$ & $\begin{array}{r}12.9 \\
(2)\end{array}$ & $\begin{array}{r}13.9 \\
(2)\end{array}$ & $\begin{array}{r}10.8 \\
(4)\end{array}$ & $\begin{array}{r}10.2 \\
(4)\end{array}$ & $\begin{array}{l}8.1 \\
(4)\end{array}$ & $\begin{array}{r}7.3 \\
(4)\end{array}$ & $\begin{array}{l}8.1 \\
(4)\end{array}$ \\
\hline Lenovo & - & $\begin{array}{l}6.8 \\
(3)\end{array}$ & $\begin{array}{l}6.9 \\
\text { (3) }\end{array}$ & $\begin{array}{l}7.0 \\
\text { (4) }\end{array}$ & $\begin{array}{l}7.4 \\
(4)\end{array}$ & $\begin{array}{l}7.5 \\
(4)\end{array}$ & $\begin{array}{l}8.0 \\
(4)\end{array}$ & $\begin{array}{r}10.9 \\
(4)\end{array}$ & $\begin{array}{r}12.5 \\
(2)\end{array}$ & $\begin{array}{r}14.9 \\
(2)\end{array}$ & $\begin{array}{r}16.9 \\
(1)\end{array}$ & $\begin{array}{r}16.9 \\
(1)\end{array}$ & $\begin{array}{r}19.4 \\
(1)\end{array}$ \\
\hline Toshiba & - & - & $\begin{array}{l}3.3 \\
\text { (5) }\end{array}$ & $\begin{array}{l}3.8 \\
\text { (5) }\end{array}$ & $\begin{array}{l}4.0 \\
(5)\end{array}$ & $\begin{array}{c}4.6 \\
(5)\end{array}$ & $\begin{array}{l}5.0 \\
\text { (5) }\end{array}$ & - & - & - & - & - & - \\
\hline Asus & - & - & & - & - & - & - & $\begin{array}{l}5.4 \\
\text { (5) }\end{array}$ & $\begin{array}{l}5.7 \\
(5)\end{array}$ & $\begin{array}{l}6.9 \\
(5)\end{array}$ & $\begin{array}{l}6.3 \\
(5)\end{array}$ & $\begin{array}{l}6.9 \\
\text { (5) }\end{array}$ & $\begin{array}{l}7.5 \\
\text { (5) }\end{array}$ \\
\hline Others & 58.6 & 55.1 & 53.8 & 49.8 & 46.5 & 44.9 & 42.8 & 40.0 & 42.8 & 41.2 & 40.8 & 40.5 & 33.4 \\
\hline \multicolumn{14}{|c|}{$\begin{array}{l}\text { Sources: Retrieved on February, 2014. [1]: } \mathrm{http} / / / \mathrm{www} . \text { gartner.com/newsroom/id/492098 }\{\text { Othe } \\
\text { id numbers of the same website are ([2] id/492237, ([3] id/500384, [4] id/584210, [5] id/856712 } \\
\text { [6] id/1279215, [7] id/1519417, [8] id/1893523, [9] id/2301715, [10]id/2647517, [11] id/2647517 } \\
{[12], \mathrm{id} / 2705117,[13] \mathrm{id} / 2960125}\end{array}$} \\
\hline
\end{tabular}

\section{Challenges faced by Lenovo in acquiring IBM $\times 8.6$ Server business and impact of deal}

\subsection{Approval by regulatory bodies in the United States, China, Canada, European Commission and Other Countries:}

Lenovo, x86 Server deal needs approval from USA, China, Canada, European commission and other countries. The Chinese Ministry of Commerce (MOFCOM), anti-monopoly department has approved the acquisition of IBM's X86 servers, blade networking and maintenance operations in the beginning of July 2014 (Osborne (2014c)). The Europe has also granted approval for the deal (Morgan (2014b)). US regulators were 
concerned with national security which may be weakened with deal since "Chinese spies" may be able to access the Pentagon's servers which are of IBM make as per their perception. Under the agreements of deal, Lenovo will take over the maintenance of IBM servers implemented in Pentagon. Concerns of cyber attacks and spying are exchanged between China and US in the recent past. Amid all concerns, the Committee on Foreign Investment in the United States (CFIUS) approved the proposed sale of IBM x86-based server business to Chinese PC maker Lenovo (Gagliordi (2014)). Competition Commission of India ( $\mathrm{CCl}$ ), the fair trade watchdog has given approval to the deal. Lenovo operates in India through its subsidiary Lenovo (India) Private Ltd (PTI (2014)).

\subsection{Security concerns of US government}

IBM's servers are used in communication networks and datacenters that support the Pentagon's systems. These servers, if maintained by Chinese Company may be threat for US national security. To address the concerns of CFIUS, it is reported that IBM will maintain the servers on Lenovo's behalf "for an extended period" after the sale is finalized. Maintenance could range from software updates to changes in hardware components (Osborne (2014a), Cobb (2015)).

\subsection{Price of the deals}

GlobalFoundries (GF), Fujitsu, Dell Inc., and Lenovo are reported as potential bidder to buy IBM's $\times 86$ server business. GF deal could not materialize due to two reasons. (i) GF was more interested in acquiring IBM's engineering expertise and intellectual property, rather than buying the chip-making facilities (Barker (2014a)). (ii) IBM was willing to give GF $\$ 1$ billion to take the chip manufacturing unit, but GF demanded \$2 billion (Davis (2014), Barker (2014b)). Fujitsu was willing to pay more than US\$2.3 billion but looking for more time to make a firm offer and Dell Inc. was never serious in making offer. On the other hand IBM was keen to sell off the server unit due to lack of demand in the market and financial necessity. Lenovo was in constant touch with IBM for more than a year. Lenovo agreed to pay US $\$ 2.3$ billion which was below the bottom end of the range of $\$ 2.5$ billion to $\$ 4.5$ billion discussed in the first round of talks between Lenovo \& IBM (Bloomberg News (2014a, 2014b)). IBM and Lenovo agreed on deal though it was below the bottom end.

\subsection{Impact on IBM}

IBM says the sale of its $x 86$ server businesses will allow the company to focus on system and software innovations such as cognitive computing business, 
big data business and cloud computing infrastructure (Barker (2014a)). In January 2014, IBM announced a plan to spend US\$1billion building up its Watson software business, and \$1.2billion on datacenters for cloud computing. It is almost equal to its earnings from selling its $x 86$ server business (Ranger (2014)).

In July 2014, it was reported that IBM will remain interested in chips after this deal and will spend \$3billion on R\&D over the next five years to make sure that its processors can keep up with the demands of cloud computing and big data applications, including examining options for post-silicon chips (Barker (2014a)).

VAR Guy (2014) reported that worlds of storage, networking and computing are converging. IBM has been pitching PureFlex System, PureApplication System and PureData system into the converged data center market. On the other hand Cisco, Dell, HP and Oracle each have their own converging strategies. How IBM will cope with this technology competition of pure system strategy $\mathrm{v} / \mathrm{s}$ converged system strategy after selling off the x86 server business. It is yet to be seen.

VAR Guy (2014) further reported that IBM has been promoting x86 servers and the PureSystem strategy aggressively to managed services providers (MSP). The objective was that the MSPs and cloud services providers (CSPS) will build next-generation data centers using IBM's infrastructure. IBM would need a new strategy after exit from the x86 server businesses. In addition, IBM's software business will be impacted without $x 86$ servers. IBM needs to look for space to bundle its software components. The deal will also impact IBM strategy with respect to $\times 86$ server based infrastructure to compete in cloud business domain.

\subsection{Impact on activities of Lenovo}

Lenovo will take control of IBM's System X, BladeCenter and Flex System blade servers and switches, x86-based Flex integrated systems, NeXtScale and iDataPlex servers and associated software, blade networking and maintenance operations. IBM's 7500 x86 business employees who are part of executive team, development team, sales team, engineers, are transferred to Lenovo (Osborne (2014a), Turner (2014)).

Lenovo high-end product line will be IBM's System $X$ and Flex servers with x86 chips for enterprise segment and Lenovo's ThinkServer products will be for small and medium-size businesses (Shah (2014)). It means Lenovo will have its reach to both segment of the industry (Blake (2014)).

Lenovo Group has reported it has achieved US $\$ 10.4$ billion in revenue for the first quarter of the 2014 financial year, an 18\% increase year-over-year 
(Chanthadavong (2014)). Lenovo Q2, 2014 revenue was US\$ 10.5 billion achieving YoY growth of $7 \%$. The details of financial parameters are given in Table 5. Lenovo's revenue in Q3 2014 from China was 29\% of its total revenue. Its home market revenue is increased only by $1 \%$ to US\$ 4.1 Billion. It means Lenovo is facing tough competition in home market.

Further, it was reported that its $3^{\text {rd }}$ quarter revenues was US $\$ 14.1$ billion, up by $31 \%$ year-on-year basis. Adjusted pretax profit, excluding costs for the company's takeovers of Motorola Mobility and IBM's x86 server business, rose $8 \%$ to US\$ 348 million. Including these costs, net profit for the three months to December fell 5\% to US\$253 million (News (2015b). It is reported by many experts that recently completed mergers of Motorola Mobility and IBM Corp's X86 server unit helped Lenovo to boost its revenue during Q4 of 2014.

Table 5. Financial parameters of Lenovo for the Year 2014

\begin{tabular}{|c|c|c|c|c|}
\hline $\begin{array}{l}\text { Yearl } \\
\text { Quarter }\end{array}$ & Account Head & Amount & Increase & Source \\
\hline Q1 (2014) & Revenue & $\begin{array}{l}\text { US } \$ 10.4 \\
\text { Billion }\end{array}$ & $\begin{array}{l}18 \% \\
\text { (YoY) }\end{array}$ & $\begin{array}{l}\text { Chanthadavong } \\
(2014)\end{array}$ \\
\hline Q2 (2014) & Revenue & $\begin{array}{l}\text { US \$ } 10.5 \\
\text { Billion }\end{array}$ & $\begin{array}{l}7 \% \\
\text { (YOY) }\end{array}$ & News (2014c) \\
\hline Q2 (2014) & Operating Profit & $\begin{array}{l}\text { US \$ } 329 \\
\text { Million }\end{array}$ & $\begin{array}{l}24 \% \\
(Y \circ Y)\end{array}$ & News (2014c) \\
\hline Q2 (2014) & Net Profit & $\begin{array}{l}\text { US \$ } 262 \\
\text { Million }\end{array}$ & $\begin{array}{l}19 \% \\
\text { (YOY) }\end{array}$ & News (2014c) \\
\hline Q3 (2014) & Revenue & $\begin{array}{l}\text { US } \$ 14.1 \\
\text { Billion }\end{array}$ & $\begin{array}{l}31 \% \\
\text { (YoY) }\end{array}$ & News (2015b). \\
\hline Q3 (2014) & $\begin{array}{l}\text { Adjusted Pre-Tax } \\
\text { profit (Excluding } \\
\text { the cost of Motorola } \\
\text { Mobility \& IBM x86 } \\
\text { Servers }\end{array}$ & $\begin{array}{l}\text { US\$ } 348 \\
\text { Million }\end{array}$ & $8 \%$ & News (2015a) \\
\hline Q3 (2014) & $\begin{array}{l}\text { Net Profit (Including } \\
\text { cost of Motorola } \\
\text { Mobility \& IBM x86 } \\
\text { Server Business }\end{array}$ & $\begin{array}{l}\text { US\$ } 253 \\
\text { Million }\end{array}$ & $-5 \%$ & News (2015a) \\
\hline
\end{tabular}

It can absorb losses of recently bought x 86 server unit of IBM and may revive the loss making units. With this deal Lenovo will have an extra US $\$ 5$ billion in revenue, and expand its $\times 86$ server market share from the 6th to the 3rd place in the world (Jiayi (2014)) as evident from the data given in Table 7 and table 8. It is also evident from the sentiments of the investors in the stock market. 
Its shares rose as much as $9 \%$ before ending the day up by $1.2 \%$ on the Hong Kong Stock Exchange on the day of deal announcement (BBC News (2014)) and also from the overall growth of its market valuation in the last decade.

It can be seen from the data given in table 6 that Lenovo market is mainly in China. On the other hand IBM has X86 servers in other major markets. The deal will be a boost to Lenovo to make its presence in high growth server market such as India where its presence is almost zero but IBM is one among three top players (Punit (2014)). As per the report of Team Channelworld (2014) server shipments in India grew $18.8 \%$ during Q3 of 2014. Team Channelworld (2014) further reported that "x86 servers fuelled the growth in Q3 with 18.9\% YoY shipment growth, Unix-based hardware revenue also grew but only by 7.6 percent as compared to last year." In another large Indian market Lenovo had to compete with HP and Dell on behalf of IBM.

Table 6. Lenovo and IBM x86 server shipments in 2Q2014 across the World

\begin{tabular}{|l|l|l|l|}
\hline SN & Region/Country & Lenovo Share & IBM Share \\
\hline 1 & China & 70.0 & 28.0 \\
\hline 2 & Asia/Pacific Ex China & 0.0 & 19.0 \\
\hline 3 & Middle East \& Africa & 0.0 & 04.0 \\
\hline 4 & Eastern Europe & 0.0 & 04.0 \\
\hline 5 & Western Europe & 7.0 & 20.0 \\
\hline 6 & Latin America & 2.0 & 06.0 \\
\hline 7 & North America & 21.0 & 15.0 \\
\hline 8 & Japan & 0.0 & 4.0 \\
\hline & Total & 100.0 & 100.0 \\
\hline
\end{tabular}

Source:Gartner Quarterly Server Statistics, Credit Suisse

According to Patrizio (2014), this deal will put Lenovo in a position wherein Lenovo through IBM Global Services, will be in a position to offer clients, servers, tablets and smartphones in one package deal, something no other vendor such as HP and Dell will have. With the inclusion of IBM's technology of high-end servers to its portfolio, Lenovo will target customers for applications such as analytics and databases (Shah (2014)).

Cobb (2015) reported that a radical change in the development of $x 86$ server technologies is occurring through a little known concept called converged infrastructure $(\mathrm{Cl})$ which will eliminate the need of many external components such as storage arrays, external high speed networks, disparate backup architectures etc. Lenovo may exploit it for capturing and reviving the $x 86$ server markets. Further, security will take on an even more important role as 
these dense servers perform more and more functions that were formally decomposed across a corporate enterprise data center.

Table 7. China $x 86$ server market share by Shipments

\begin{tabular}{|c|c|c|c|c|c|c|c|c|c|c|c|}
\hline SN & \multirow{2}{*}{\multicolumn{3}{|c|}{ Manufactures }} & \multicolumn{5}{|c|}{2014 H1[1] (Shipments) } & \multirow{2}{*}{\multicolumn{3}{|c|}{$\frac{\text { Q4 } 2014 \text { (Rev.) }}{\text { China[3] }}$}} \\
\hline & & & & \multirow{2}{*}{\multicolumn{3}{|c|}{$\frac{\text { China [1] }}{23.91}$}} & \multicolumn{2}{|c|}{ World [2] } & & & \\
\hline 1 & \multicolumn{3}{|c|}{$\begin{array}{l}\text { Lenovo (including } \\
\text { IBM x86 Servers) }\end{array}$} & & & & & 1.65 & \multicolumn{3}{|c|}{19.32} \\
\hline 2 & \multicolumn{3}{|c|}{ Dell } & \multicolumn{3}{|c|}{20.36} & \multicolumn{2}{|c|}{22.16} & \multicolumn{3}{|c|}{18.88} \\
\hline 3 & \multicolumn{3}{|c|}{ Inspur } & \multicolumn{3}{|c|}{14.34} & \multicolumn{2}{|r|}{ - } & \multicolumn{3}{|c|}{19.50} \\
\hline 4 & \multicolumn{3}{|c|}{ Cisco } & \multicolumn{3}{|c|}{-} & \multicolumn{2}{|c|}{3.37} & \multicolumn{3}{|c|}{-} \\
\hline 4 & \multicolumn{3}{|c|}{ Huawei } & \multicolumn{3}{|c|}{13.17} & \multicolumn{2}{|r|}{-} & \multicolumn{3}{|c|}{13.24} \\
\hline 5 & \multicolumn{3}{|c|}{$\mathrm{HP}$} & \multicolumn{3}{|c|}{11.37} & \multicolumn{2}{|c|}{25.69} & \multicolumn{3}{|c|}{13.85} \\
\hline 6 & \multicolumn{3}{|c|}{ ODM } & & & & \multicolumn{2}{|c|}{15.55} & \multicolumn{3}{|c|}{-} \\
\hline 7 & \multicolumn{3}{|c|}{ Sugon } & \multicolumn{3}{|c|}{9.28} & \multirow{2}{*}{\multicolumn{2}{|c|}{21.58}} & \multicolumn{3}{|c|}{09.53} \\
\hline 8 & \multicolumn{3}{|c|}{ Others } & \multicolumn{3}{|c|}{7.21} & & & & 05.68 & \\
\hline & & Tota & & & 100.0 & & & 0.0 & & 100.0 & \\
\hline Year* & $\begin{array}{c}200 \\
4\end{array}$ & $\begin{array}{c}200 \\
5\end{array}$ & $\begin{array}{c}200 \\
6\end{array}$ & $\begin{array}{c}200 \\
7\end{array}$ & $\begin{array}{c}200 \\
8\end{array}$ & $\begin{array}{l}20 \\
09\end{array}$ & $\begin{array}{l}20 \\
10\end{array}$ & $\begin{array}{c}201 \\
1\end{array}$ & $\begin{array}{c}201 \\
2\end{array}$ & $\begin{array}{c}201 \\
3\end{array}$ & $\begin{array}{l}201 \\
3^{\star \star}\end{array}$ \\
\hline $\begin{array}{c}\text { Shar } \\
\mathrm{e}\end{array}$ & $\begin{array}{l}0.3 \\
\%\end{array}$ & $\begin{array}{l}0.3 \\
\%\end{array}$ & $\begin{array}{c}0.3 \\
\%\end{array}$ & $\begin{array}{c}0.3 \\
\%\end{array}$ & $\begin{array}{l}0.4 \\
\%\end{array}$ & $\begin{array}{c}0.5 \\
\%\end{array}$ & $\begin{array}{c}0.5 \\
\%\end{array}$ & $\begin{array}{l}0.7 \\
\%\end{array}$ & $\begin{array}{c}0.9 \\
\%\end{array}$ & $\begin{array}{l}1.0 \\
\%\end{array}$ & $\begin{array}{c}13.9 \\
\%\end{array}$ \\
\hline $\begin{array}{l}\text { [1]: So } \\
\text { [2]: So } \\
{ }^{*} \text { Marke } \\
\text { ** Lenc } \\
\text { (2014) }\end{array}$ & $\begin{array}{l}\text { ce: } h \\
\text { ce: I } \\
\text { Shar } \\
0+1\end{array}$ & $\begin{array}{l}\text { ://Ww } \\
\text { "Wor } \\
\text { f Len } \\
\text { I marl }\end{array}$ & $\begin{array}{l}\text { idc.c } \\
\text { Iwide } \\
\text { vo of }\end{array}$ & $\begin{array}{l}\text { get } \\
\text { Iarte } \\
\text { se }\end{array}$ & $\begin{array}{l}\text { c.jsp? } \\
\text { Serv } \\
\text { mar }\end{array}$ & $\begin{array}{l}\frac{\text { onta }}{\text { Tra }} \\
\text { th. }\end{array}$ & $\frac{\mathrm{erd}=}{\mathrm{er} 2}$ & $\frac{\mathrm{CN} 2}{4 \mathrm{Q}^{2}}$ & $\frac{7321}{3]: ~ L u}$ & 2015 & \\
\hline
\end{tabular}

Based on the data given in table 7 and table 8 it can be seen that Lenovo is at third place after acquiring $\times 86$ server business in the world and first in China (based on Q1 \& Q2, 2014 data). However as reported by Luo (2015), Inspur was leader in China's x86 market during Q3, 2014 and Q4, 2014. The difference with HP and Dell is huge. It seems that it will be very difficult for Lenovo to attain number one position in world and even in China. Secondly, share of Lenovo + IBM was 13.9\% for the 9 month period of 2013 in world but during first half of 2014 it was only 11.65 as can be seen from table 7 . Though the share of Dell and HP is declining, it is taken over by other small manufacturers but not by Lenovo. It seems the attaining number one position in the world $x 86$ server market as well as in China will be difficult to Lenovo. Leopold (2015) reported that it is hard to sell but Lenovo may attempt to package desktop and laptop machines along with servers, selling to large enterprises to repeat the success of ThinkPad business in days to come. 
Singh N.P.: Lenovo Acquires IBM's x86 Low-end Server Business

Table 8. Worldwide $x 86$ server market share by Shipments

\begin{tabular}{|c|c|c|c|c|c|c|}
\hline $\mathrm{SN}$ & Manufactures & $\begin{array}{l}2012 \\
\text { Q4 [1] }\end{array}$ & $\begin{array}{l}2013 \\
\text { Q3[2] }\end{array}$ & $\begin{array}{c}\text { Sept. } \\
\text { 2013[3] }\end{array}$ & $\begin{array}{c}\text { June } \\
2014 \text { [4] }\end{array}$ & $\begin{array}{l}2014 \\
\text { Q2[4] }\end{array}$ \\
\hline \multirow[t]{2}{*}{1} & Lenovo + IBM ) & & 9.90 & - & - & 11.65 (III) \\
\hline & IBM & 16.7 & - & 5.40 & 4.40 & - \\
\hline 2 & Dell & 22.9 & 19.70 & 22.30 & 21.20 & 20.16 (II) \\
\hline 3 & ODM & & - & - & - & 15.55 \\
\hline 4 & Cisco & 5.0 & 2.70 & 2.60 & 5.40 & 3.37 \\
\hline 5 & $\mathrm{HP}$ & 32.7 & 27.00 & 26.70 & 25.90 & $25.69(\mathrm{I})$ \\
\hline 6 & Huawei & & 2.50 & - & - & - \\
\hline 7 & Hitachi & & & 2.40 & 2.30 & \\
\hline 8 & Inspur & & & & 2.20 & \\
\hline 9 & Fujitsu & 3.1 & 2.70 & 2.00 & 2.40 & - \\
\hline 10 & Teradata & & & 1.90 & - & \\
\hline \multirow[t]{2}{*}{11} & Others & & 35.50 & 36.60 & 36.30 & 21.58 \\
\hline & Total & & 100.0 & 100.0 & 100.0 & 100.0 \\
\hline \multicolumn{7}{|c|}{$\begin{array}{l}\text { [2]: http://www.idc.com/getdoc.jsp?containerld=prCN25173214 } \\
\text { [3]: http://www.itcandor.com/wp-content/uploads/2014/01/server-share.png } \\
\text { [4]: } \\
\text { [1]: http://www.itcandor.com/wp-content/uploads/2014/09/server-share1.png } \\
\text { Server-Markw./wsusinesswire.com/news/home/20130227006664/en/Worldwide- } \\
\text { revenue) }\end{array}$} \\
\hline
\end{tabular}

Burt (2013) reported that Lenovo will not invest in its own software stacks. It will invest its resources on building top-rated servers and interface to work with software partners such as Microsoft, VMware and Red Hat. It will provide customers of Lenovo the best of breed software's and interoperability since these companies work with almost all the manufacturers of the servers.

\subsection{Impact on other Stakeholders}

As per deal, Lenovo will take responsibility of 7500 employees who work for the System X division around the world (Morgan (2014b). Massive strike is reported at IBM factory in China by the workers. Jiayi (2014) reported that on 03 March 2014, more than 1,000 workers at the server-making IBM ISTC factory in Shenzhen, Guangdong, staged strikes and protested against the company's lump sum severance package. According to a Shenzhen TV channel's report, IBM ISTC gave two choices for the workers: (i) "willingly" leave IBM before March 12 with compensation plus an extra 6,000 Yuan, (ii) stay and "automatically" become Lenovo employees with the same amount of compensation. None of the plan is in accordance with the labor laws in China. On the other hand workers were expecting compensation based on computation, i.e., average monthly salary $\times$ years of service $\times 2+$ one month of salary. Workers are also raising issues such as Occupational Health and 
Safety (OHS) checkups, extra hours working, and extra compensation for the female workers who were pregnant or are nursing a baby. Such strikes happen in China when companies are acquired and new management is not able to compensate the employees. It happens at the time of Nokia \& Microsoft deal, and proposed deal between Apollo tires and Cooper Tire \& Rubber Co. However, Lenovo pacified employees and made a statement that "To ensure a smooth transition, Lenovo is committed to provide opportunity for all employees from IBM's X86 server department who transfer to Lenovo, without any reduction of their wages and benefits" (Ruwitch and Pomfret (2014)). There could be three reasons for such an assurance. Firstly, it is difficult to get technical human resources as experienced as exiting workforce of IBM. Secondly, this shortage of workforce tilted the balance in favor of workforce. Thirdly, workforces are now more aware of their rights and regulations in the countries across the globe. As reported recently, jobs cuts arenot ruled out in days to come by Lenovo (The Australian (2014)). It is reported that there will be no impact on EMC and Lenovo partnership due to x86 server deal (News (2015b)).

\subsection{Channel partners:}

It is reported by Haber (2014a), Rishi (2014), and VAR Guy (2014) that this deal is good for channel partners since Lenovo is a channel focused company. Haber (2014a) further reported that the deal provides great opportunity for channel partners to extend their business around both Lenovo and IBM products, such as the Power Systems, mainframe and storage products. Lenovo addressed the main concerns of channel partners at Lenovo Accelerate 2014 partner conference which was sold out six weeks prior to the conference registration deadline. It shows the interest of channels partners in announcement of Lenovo for partners. Haber (2014b) mentioned that the channel-centric vendor's business in North America has seen big year-overyear growth: $65 \%$ overall revenue growth, $67 \%$ server growth and $35 \%$ growth in the SMB market. Lenovo also boasted $40 \%$ growth in its North America PC business in a market that's declining or flat at best. At the same time, 3,200 new partners signed on with Lenovo.

\subsection{Competitors}

Pimentel (2014) mentioned that Lenovo and IBM deal mean more headaches for Hewlett-Packard. Lenovo will engage HP and Dell in aggressive pricing war with a view to capture x86 server market as it has done for PC market. The only point to help competitors is that users/ organizations are reluctant to depend on a single vendor. They believe that all manufacturers are using AMD and Intel chips, the same RAM and the same disks. The only differential factor is price (Zuckerman (2012)). On the other hand Hewlett-Packard and Dell 
have aggressively pursuing to win over IBM's large customer base for their products. However, IBM and Lenovo have tried to diffuse any uncertainty with respect to customer segment for different products. It is reported by IBM and Lenovo that their respective product lines will remain intact and that levels of support to the existing customers will remain the same (Shah (2014)).

Table 9. Worldwide All Server Market Revenue Share (US\$)

\begin{tabular}{|c|c|c|c|c|c|c|c|}
\hline Vendor & 2008 [1] & $2009[2]$ & $2010[3]$ & 2011[3] & 2012[4] & 2013[4] & 2014[5] \\
\hline $\mathrm{HP}$ & 22.9 & 27.6 & 30.8 & 30.5 & 27.2 & 26.6 & 26.2 \\
\hline IBM & 24.0 & 22.3 & 31.3 & 29.0 & 30.3 & 25.6 & 18.4 \\
\hline Dell & 11.0 & 12.4 & 14.7 & 14.7 & 15.5 & 16.6 & 17.6 \\
\hline Hitachi & 06.1 & 09.6 & - & - & - & - & - \\
\hline Sun & 09.8 & 08.6 & - & - & - & - & - \\
\hline Oracle & - & - & 06.3 & 06.1 & 05.1 & 04.7 & 04.6 \\
\hline Cisco & - & - & - & - & 03.1 & 04.5 & 05.7 \\
\hline $\begin{array}{l}\text { ODM } \\
\text { Direct }\end{array}$ & - & - & - & - & 03.4 & 05.7 & 07.8 \\
\hline Fujitsu & 09.5 & 06.5 & 04.4 & 04.8 & - & - & - \\
\hline NCR & 04.7 & 03.7 & - & - & - & - & - \\
\hline Others & 11.7 & 12.0 & 12.5 & 14.9 & 15.5 & 16.3 & 19.7 \\
\hline $\begin{array}{l}\text { Total } \\
\text { Revenue }\end{array}$ & $\begin{array}{l}54.4 \\
\text { Billion }\end{array}$ & $\begin{array}{l}42.2 \\
\text { Billion }\end{array}$ & $\begin{array}{l}48.92 \\
\text { Billion }\end{array}$ & $\begin{array}{l}52.79 \\
\text { Billion }\end{array}$ & $\begin{array}{l}52.03 \\
\text { Billion }\end{array}$ & $\begin{array}{l}49.72 \\
\text { Billion }\end{array}$ & $\begin{array}{l}50.9 \\
\text { Billion }\end{array}$ \\
\hline \multicolumn{8}{|c|}{$\begin{array}{l}\text { [1] http://www.itcandor.com/world-server-market-forecast-q309/ } \\
\text { [2] }] \text { http://www.itcandor.com/server-forecast-q110/ } \\
\text { [3] http://www.gartner.com/newsroom/id/1935717 } \\
\text { [4] http://www.reuters.com/article/2014/02/27/ma-idc-idUSnBw266752a+100+BSW20140227 } \\
\text { [5] http://www.serverwatch.com/server-news/global-server-market-grew-to-50.9-billion-in- }\end{array}$} \\
\hline
\end{tabular}

Table 10. Worldwide: Market Share of Server Revenue Estimates (Q4)

\begin{tabular}{|c|c|c|c|c|c|c|c|}
\hline Vendor & $2008[1]$ & $2009[1]$ & $2010[2]$ & 2011[3] & $2012[4]$ & $2013[4]$ & 2014[5] \\
\hline IBM & 33.4 & 32.7 & 35.5 & 33.7 & 34.9 & 26.5 & 18.2 \\
\hline $\mathrm{HP}$ & 30.0 & 31.3 & 30.4 & 26.9 & 24.8 & 28.1 & 26.5 \\
\hline Dell & 10.7 & 12.1 & 13.1 & 14.8 & 14.3 & 15.2 & 17.0 \\
\hline Sun /Oracle & 09.6 & 07.6 & 05.5 & 05.3 & 04.1 & 4.2 & 04.1 \\
\hline $\begin{array}{l}\text { Fujitsu/Fujitsu } \\
\text { Siemens }\end{array}$ & 04.3 & 04.5 & 03.8 & 03.6 & - & - & - \\
\hline Cisco & & & & & 03.3 & 04.7 & 06.2 \\
\hline ODM Direct & & & & & & & 08.9 \\
\hline Others & 12.0 & 11.8 & 11.7 & 15.8 & 18.7 & 21.3 & 18.4 \\
\hline Total & 100 & 100 & 100 & 100 & 100 & 100 & 100 \\
\hline Total (Billion) & 12.11 & 12.61 & 14.68 & 13.91 & 14.62 & 13.66 & 12.74 \\
\hline \multicolumn{8}{|c|}{$\begin{array}{l}\text { [1]. http://www.gartner.com/newsroom/id/1307717 } \\
\text { [2]. } \frac{\text { http:///www.gartner.com/newsroom/id/1561014 }}{\text { [3]. }} \text { http://www.gartner.com/newsroom/id/1935717 } \\
\text { [4]. http://www.gartner.com/newsroom/id/2671315 }\end{array}$} \\
\hline
\end{tabular}


Further, the data presented in Table 9, Table 10, Table 11, and Table 12 reveals the growth of revenue in all server market in general and $x 86$ server segment in particular during 2014. Based on the data presented in table 9 and Table 10, it can be seen that HP and Dell have almost keeping their market share intact within limit of variation for such a competitive business. However, IBM share is taken over by Lenovo or others. Total yearly revenue is also stabilized around US\$50 Billion.

Table 11. China x86 Server Market

\begin{tabular}{|c|c|c|c|}
\hline $\begin{array}{l}\text { Year \& } \\
\text { Quarter }\end{array}$ & Units & Revenue + YoY Growth & Source \\
\hline Q3 2007 & 158,000 & 2.89 Billion Yaun & PR Newswire (2008) \\
\hline Q1-Q3 2007 & $423,000(+16.1 \%)$ & 7.95 Billion Yaun (+12.6\%) & CMIC (2008) \\
\hline Q3 2008 & $182,000(+15.2 \%)$ & 3.23 Billion Yaun $(+11.8 \%)$ & PR Newswire (2008) \\
\hline Q1 2011 & & US\$ 809 Million & Thompson (2013) \\
\hline Q2 2011 & & US\$ 879 Million & Thompson (2013) \\
\hline Q3 2011 & & US\$ 930 Million & Thompson (2013) \\
\hline Q4 2011 & & US\$1134 Million & Thompson (2013) \\
\hline 2011 (Full) & & US\$ 3.753 Billion & Thompson (2013) \\
\hline Q1 2012 & & US\$ 907 Million & Thompson (2013) \\
\hline Q2 2012 & $316,000(+5.6 \%)$ & US\$ 1013 Million & Chen (2012) \\
\hline Q3 2012 & & US\$ 1112 Million & Thompson (2013) \\
\hline Q4 2012 & & US\$ 1238 Million & Thompson (2013) \\
\hline 2012 (Full) & & US\$4.269 Billion & Thompson (2013) \\
\hline Q1 2013 & $286,000(+03.9 \%)$ & US\$ 870 Million (+09.5\%) & China Daily (2013) \\
\hline Q2 2013 & $364,000(+15.4 \%)$ & US\$1.06 Billion (+19.6\%) & Press Release (2013) \\
\hline Q1 2014 & $350,000(+22.9 \%)$ & US\$1.07 Billion (+24,5\%) & 4-traders (2014) \\
\hline Q2 2014 & $448,000(+22.2 \%)$ & US\$1.43 Billion (+34.6\%) & $\begin{array}{l}\text { ChinaTech News } \\
(2014)\end{array}$ \\
\hline Q4 2014 & & US\$1.82 Billion (+24.4\%) & Luo (2015) \\
\hline
\end{tabular}

Based on the data given in table 11 and table 12, it can be seen that revenue and shipment of $x 86$ servers has increased during 2014. It is reported by Chen (2012) that China's Large internet players including Baidu, Alibaba, Tencent, and Qihoo 360 are major drivers behind the 2-way x86 servers growth. In addition, analysts attribute this growth to the Chinese government's vigorous tech promotion efforts and its booming internet industry. Premier $\mathrm{Li}$ Keqiang has put forward the "Internet+" strategy based on the integration of IT and industry (Luo (2015)). Kerner (2015) reported that hyper data center deployments by private cloud providers and interrelated Greenfield 
Singh N.P.: Lenovo Acquires IBM's x86 Low-end Server Business

opportunities attached to Internet of Things (IOT) will derive growth of x86 servers across the globe in near future.

Table 12. World x86 Server Market

\begin{tabular}{|c|c|c|c|}
\hline $\begin{array}{l}\text { Year \& } \\
\text { Quarter }\end{array}$ & Units (Million) & Revenue (US\$ Billion) & Source \\
\hline Full 2009 & 6.40 & 23.70 & Business Wire (2010) \\
\hline Full 2010 & $7.40(+16.6 \%)$ & 30.60(+28.7\%YoY Growth) & Business Wire (2011) \\
\hline Q3 2010 & 1.90 & 07.80 & \\
\hline Q4 2010 & $2.00(+6.7 \%)$ & 09.00 (+21.4\%YoY Growth) & Business Wire (2011) \\
\hline Full 2011 & $8.00(+3.7 \%)$ & 34.40 (+07.7\%YoY Growth) & Techpowerup (2012) \\
\hline Q1 2011 & 1.90 & 08.47 (+17.5\%YoY Growth) & Thompson (2013) \\
\hline Q2 2011 & & 08.70 (+17.7\%YoY Growth) & Thompson (2013) \\
\hline Q3 2011 & $2.0(+4.0 \%)$ & 09.01 (+09.5\%YoY Growth) & Olavsrud (2011) \\
\hline Q4 2011 & $2.10(+2.9 \%)$ & 09.39 (+02.6\%YoY Growth) & IBM Systems (2012) \\
\hline Full 2012 & $8.00(-0.4 \%)$ & 35.57 (+04.1\%YoY Growth) & Business Wire (2013) \\
\hline Q1 2012 & & 08.96 (+05.7\%YoY Growth) & Thompson (2013) \\
\hline Q2 2012 & & 09.19 (+05.6\%YoY Growth) & Thompson (2013) \\
\hline Q3 2012 & $2.10(+1.5 \%)$ & 09.37 (+04.0\%YoY Growth) & Thompson (2013) \\
\hline Q4 2012 & $2.10(+3.7 \%)$ & 10.10 (+06.0\%YoY Growth) & Business Wire (2013) \\
\hline Full 2013 & $9.76(+2.60 \%)$ & 30.72 (-14.0\%YoY Growth) & Morgan (2014a) \\
\hline Q1 2013 & & 09.12 (+01.8\%YoY Growth) & Thompson (2013) \\
\hline Q2 2013 & $1.90(-0.1 \%)$ & 08.70 (-01.3\%YoY Growth) & IDC Report \\
\hline Q3 2013 & 2.20 & 09.50 (+02.8\%YoY Growth) & Press Release (2013) \\
\hline Q1 2014 & $2.10(+2.50 \%)$ & 08.90 (+04.9\%YoY Growth) & Press Release (2014) \\
\hline Q2 2014 & $2.20(+1.50 \%)$ & 9.80 (+7.8\% YoY Growth) & ChinaTech News (2014) \\
\hline Q3 2014 & $2.38(+1.20 \%)$ & 10.70 (+7.4\% YoY Growth) & Kerner (2014) \\
\hline Q4 2014 & $2.50(2.9 \%)$ & 11.50 (+7.1\% YoY Growth) & Business Wire (2015) \\
\hline
\end{tabular}

\section{Analysis of Data \& Interpretation with respect to research questions}

Based on the analysis of data in the form of event analysis, content analysis, and trend analysis presented in earlier sections, the possible answers to 9 research questions are summarized in the following sub sections.

Research Question 1: Will Lenovo repeat success of IBM's previous ThinkPad business deal? 
x86 server business is a different business segment. The strategies of ThinkPad business may not work for this segment. Based on the analysis of data collected in this article, it can be inferred that Lenovo may repeat success of IBM ThinkPad Business deal but rate of success will be slow and in the meantime innovations by all players of ecosystem may change very basic nature of computing infrastructure. However, it depends on acceptability of $\mathrm{x} 86$ servers as low cost servers by high-end and high cost enterprise business model vis-à-vis quality of these servers. Secondly, it will depend on growth of implementation of low cost server technology in SME segment. In addition, Lenovo will face stiff competition in local market from local manufacturers specifically from Inspur. In nutshell, repeat of success will depend on (i) acceptability of low cost model by high-end computing, (ii) expansion of $\times 86$ businesses by Lenovo outside China, (iii) creation of synergies between IBM and Lenovo, (iv) implementation of X86 servers by SMEs, (v) business friendly geopolitical environment, (vi) digitization programs of government services in many countries, and (iv) overall innovations by all stakeholders of $x 86$ server eco systems.

Research Question 2: Will it expand Lenovo markets for its existing products as well as products of acquired unit of $\times 86$ servers or partners products?

The data presented in table 6 reveals that Lenovo server business was mainly in China with negligible presence in Asia/Pacific (including large market of India), Middle-East, Africa, Eastern Europe, Western Europe and Japan. On the other hand IBM has presence in all these markets. The deal will expand x86 server business of Lenovo in these markets. Lenovo may push other products also along with X86 server and PC in these markets. Lenovo's ThinkServer and IBM's $\times 86$ server portfolios complement each other. Lenovo's portfolio is primarily focused on small and medium businesses, while IBM's portfolio is focused on large enterprises and data center customers. The companies' customer bases are complementary as well, and both current and future customers will have access to stronger business partners with a broad portfolio of products and services. The following two quotes may explain the expansion strategy of Lenovo.

(i) "Our strengths lie in scalability, operational efficiency, and a broad channel presence that gives IBM the access to Lenovo's strong server portfolio, including its think server range" by Chen Xudong SVP, Lenovo Group (Rishi (2014).

(ii) “Lenovo's relationship with other providers like VMware, Oracle, and EMC will enable our partners to access a wide range of storage portfolio, databases, and middleware, which was a challenge with IBM earlier", Amar Babu, MD, Lenovo India (Rishi (2014).

Research Question 3: Is Synergy Trap Hypothesis true in acquisition of $\times 86$ server business? 
As per synergy trap hypothesis immediately before and after an acquisition announcement, the acquiring firm's stock price is negatively affected and the target firm's stock price is positively affected (Myeong-Cheol, et al (2002)). It can be seen from the movement of the stock prices provided at yahoofinance.com and at other sites that Lenovo stock prices were negatively affected but not much positive impact was on IBM stock. It is also reported by Clover (2014) that to some extent the synergy trap hypotheses is true. The stock prices of Lenovo have fallen at Hong Kong exchange in the month of November, 2014 a period after the deal.

Research Question 4: Will it help Lenovo to acquire more loss making units if any and do innovation in server manufacturing technology and processes?

It looks difficult to buy businesses of biggies such as Dell, HP and oracle. However, it may acquire some small niche players in future. Further, innovation within may not be possible for Lenovo due to priorities of integration of acquired businesses which also include integration of workforce as well other partners of value chain including customers. However, integration processes results at times in to process innovation.

Research Question 5: Is inorganic expansion path better for faster growth in high tech electronic industry?

Naidu (2015) commented that increasing costs, higher gestation period \& lower RoE in setting plant may prompt big cement companies to buy established cement plants of smaller companies. This is applicable to high tech companies also. If one plans to closer to a dominant market position, plan to bring cost efficiencies through economies of scale and synergies with new management skills than inorganic path is right. Das and Kapil (2015) reported that financially strong, low-debt firms with high market capitalization are the typical acquirers in technology segment and they tend to be serial acquirer too in the Indian context. This fits with the Lenovo strategy of expansion as evident from the data presented in Table 1. Lenovo is looking for acquiring local BPO companies (Pinaroc (2014)). This is another example that inorganic growth is more on the future agenda of Lenovo in comparison to organic growth.

Research Question 6: Will huge local market for $x 86$ servers help Lenovo to repeat the success of ThinkPad PC business acquisition?

It is evident from the data given in table 5 that Lenovo $70 \%$ of the business is coming from local Chinese market. In addition data presented in table 9 shows the growth of $x 86$ server market in China. However, data presented in table 6 is a proof that Lenovo facing fierce competition by other local manufacturers specifically from Inspur, Huawei, and Sugon. Local market may not help Lenovo to repeat success of PC business. However, if Lenovo is 
successful in other markets served by IBM then repeat of the success is possible.

Research Question 7: Will IBM's bottom line improve?

IBM cited that it will concentrate more of a specific component of technology business rather than loss making $x 86$ server business while parting away from x86 server business. It will be suicidal for IBM if management of IBM is not able to achieve it. The pressure of strategic massages/ policies announcement by the IBM management will put pressure on IBM. It may result in to improvement in bottom line. But if one goes by Cringely (2014), future looks different for IBM. Other data sets as provided by Gartner indicate that competitors are gaining more from the deal (Saran (2014a)).

Research Question 8: Will it help Lenovo to take advantage of unique skills and knowledge of IBM's work force in $\times 86$ server domain?

Yes, the deal had helped Lenovo in acquiring unique skills and knowledge of IBM workforce. It will help Lenovo in creating synergies among two set of skilled manpower. It depends on proper integration of two set of manpower in the new set up. Sometimes it results in to negativity if the aspirations of both the groups are not addressed properly.

Research Question 9: Will it convert in to a "good opportunities" to take over a corporation when it is making loss in low demand era and have potential to grow with better management or changed management skills?

It can be seen from the data given in table 09 and table 10 that all server market is almost static around US\$50 billion per year with irregular quarterly variation. On the other hand data given in table 11 and table 12 indicates an upward growth in x86 server revenue in the last few years in China as well as across the globe. Lenovo proved in the past that its management skills are better than competitors by making PC business a great success. The $x 86$ server business showing potential in the past few years and Lenovo may convert it in to a good opportunity.

\section{Concluding Remarks}

Product range of Lenovo has end to end offerings ranging from smart phones (Motorola), tablets and PCs to storage, networking, and servers. It is reported by Enderle (2015) that Lenovo's networking and storage portfolios are light but far better equipped with mobile devices. It has partnership with companies like EMC and IBM to fill the product gaps. This is not the case of its competitors, i.e., Dell and HP. 
A decade ago Lenovo acquires ThinkPad PC business of IBM. After approximately 10 years Lenovo became largest manufacturer of PC in the world market as evident from the data given in table 2. The $\times 86$ servers deal will make Lenovo leader in the low end server market in the next 5 years or 10 years, only coming year will prove or disprove it. Lenovo acquiring commodity x86 server portfolios is a long- term strategic win for IBM, Lenovo, business partners, customers, and the 7,500 IBM employees. The success of Lenovo in server segment depends on the efforts of all stakeholders. All in one event looks impossible. It will help IBM to continue innovation in enterprise systems and in the highly competitive cloud computing, cognitive computing, and big data domain which may generate more revenue but it may be termed as bad decision on part of IBM in future. The reasons for the views are as under:

i. Which is the next business unit that make losses and to be sold by IBM? As reported by Perez (2015), IMB's enterprise storage business which is part of IBM's systems and technology business segment, may be a potential target for Lenovo expansion since profit in the IBM's systems and technology business segment fell by about US $\$ 1.7$ billion last year. Lenovo has ample financial resources to pursue another major corporate takeover, with its total available credit facilities amounting to US\$8.1 billion.

ii. There will be an impression in the market that IBM is not able to manage its traditional \& well accepted products business in an environment of fierce competition \& low demand.

iii. IBM is a company who best develops products and creates best knowledgeable workforce but becomes a workforce hiring agency to other companies in its domain of business.

iv. This deal gives an impression that IBM suffers from internal innovation stagnation for select category of products, operations \& processes.

v. This deal gives impression that IBM suffers from sustainable management and technology innovation for low margin products.

vi. On the other hand it carries an opposite message that IBM still a company to innovate in high- end computing segment of the industry and will bounce back with new innovation in this segment.

It could be strategic win for Lenovo who will have experienced and now have excellent work force of 7500 IBM employees at its disposal. It means it has augmented its capacity to innovate \& may sustain the profitability of the company at the same rate. However, it will be difficult to sustain the same growth rate with growing size and competition in a market segment which is not high growth oriented. Business partners, most crucial components of 
value chain of Lenovo/IBM have some concerns with respect to level of support to existing customers which Lenovo need to address aggressively to ward off any attempts by Dell and HP. Employees were agitated initially at the offer of Lenovo but after that not much is reported. However, their enthusiasm will depend on Lenovo offers and will be crucial for Lenovo's repeat success. In addition, it can be concluded that Lenovo, through IBM Global Services, will be in a position to offer its clients, servers, tablets and smart phones in one package deal, something no other vendor will have. Competing on price and its strategy of incremental innovation (Banbury and Mittal (1995) are another positive points on the side of Lenovo and it is not so in case of its main competitors

\section{References}

4-traders, (2014). Dell Leads in China x86 Server Market in Q1, December 06. Retrieved from http://www.4-traders.com/INSPUR-INTERNATIONAL-LIMI6170543/news/Dell-Leads-in-China-x86-Server-Market-in-Q1$18582166 / 20140314$

Alabaster, J. (2012). NEC sells shares in Lenovo; Japan PC joint venture unaffected. September $04 . \quad$ Retrieved from http://www.pcworld.com/article/261890/nec sells shares in lenovo japan pc i oint venture unaffected.html

Annie, (2013). Lenovo and IBM Server Deal Falls Through, May 09. Retrieved from http://news.filehippo.com/2013/05/lenovo-and-ibm-server-deal-falls-through

Das, A., \& Kapil, S. (2015). Inorganic growth of technology sector firms in emerging markets: Influence of firm-specific factors in Indian firms' M\&A activities. International Journal of Emerging Markets, 10(1), 52-72.

Banbury, C.M., \& Mitchell, W. (1995). The effect of introducing important incremental innovations on market share and business survival. Strategic Management Journal, 16(S1), 161-182. doi:10.1002/smj.4250160922

Barinka, A. (2014). Lenovo to Buy IBM Server Unit for \$2. 3 Billion amid Slump, January 14. Retrieved from http://www.bloomberg.com/news/2014-01-23/lenovoto-buy-ibm-server-unit-for-2-3-billion-amid-pc-slump.html

Barker, C. (2014). IBM and GlobalFoundries' chip tie-up unties, July 26. Retrieved from http://www.zdnet.com/ibm-and-globalfoundries-chip-tie-up-unties$\underline{70000320771 .}$.

Barker, C. (2014). IBM was willing to pay \$1bn to offload chip business, August 05. Retrieved from http://www.zdnet.com/ibm-was-willing-to-pay-1bn-to-offload-chipbusiness-7000032328/.

BBC News, Lenovo shares rise on IBM server deal, January, 24 (2014) Retrieved from http://www.bbc.com/news/business-25873801

Blake, D. (2014). How the IBM-Lenovo deal affects you, October 23. Retrieved from http://blog.shi.com/2014/10/23/how-the-ibm-lenovo-deal-affectsyou/\#.VNCXVNiZTDC 
Lenovo Said to Beat Fujitsu to IBM Servers after Dell Passed, January 24 (2014) Retrieved from http://www.bloomberg.com/news/2014-01-24/lenovo-said-tohave-beaten-fujitsu-to-ibm-deal-after-dell-passed.html

-Bloomberg News. (2014). Lenovo punished by downgrades over Motorola Mobility acquisition deal, February, $05 . \quad$ Retrieved from http://www.scmp.com/business/companies/article/1420964/lenovo-punisheddowngrades-over-motorola-mobility-acquisition

Bradley, T. (2013). Lenovo and EMC partner on storage for SMBs, January 11. Retrieved from http://www.pcworld.com/article/2025141/lenovo-and-emcpartner-on-storage-for-smbs.html

Burt, J. (2013). Lenovo Making Steady Push Into x86 Server Market, September 13. Retrieved

from http://weidaohang.org/shenghuo/h/index.php?q=aHR0cDovL3d3dy5ld2Vlay5jb2 OvcHJpbnOvc2VydmVycy9sZW5vdm8tbWFraW5nLXNOZWFkeS1wdXNoLWlud G8teDg2LXNIcnZlci1tYXJrZXQuaHRtbA==

-Business Wire. (2010). Worldwide Server Market Revenues Increase 13. 2\% in Third Quarter as Market Accelerates Further, According to IDC, December 01. Retrieved from http://www.businesswire.com/news/home/20101201005740/en/WorldwideServer-Market-Revenues-Increase-13.2-Quarter\#.VSCtqCJtvDc.

-Business Wire. (2011). CORRECTING and REPLACING Worldwide Server Market Accelerates Sharply in Fourth Quarter as Demand for Heterogeneous Platforms Leads the Way, According to IDC, March 01. Retrieved from http://www.businesswire.com/news/home/20110228007267/en/CORRECTINGREPLACING-Worldwide-Server-Market-Accelerates-Sharply\#.VRmVUCJtvDc.

-Business Wire. (2013). Worldwide Server Market Rebounds Sharply in Fourth Quarter as Demand for x86 Servers and High-end Systems Leads the Way, According to IDC, February 27. Retrieved from http://www.businesswire.com/news/home/20130227006664/en/WorldwideServer-Market-Rebounds-Sharply-Fourth-Quarter\#.VSFW8SJtvDc.

-Business Wire. (2015). Global Server Market Revenues Increase 1. 9\% in Q4, March 4. Retrieved from http://pcb.iconnect007.com/index.php/article/88484/globalserver-market-revenues-increase-19-in-q4/88487/?skin=ein.

Carsten, P. (2013). For Lenovo, ThinkPad turnaround provides blueprint for Motorola handset future, February, 13. Retrieved from http://www.reuters.com/article/2014/02/13/us-lenovo-q3-resultsidUSBREA1C01R20140213

Chanthadavong, A. (2014). Growing PC market share boosts Lenovo first quarter results, August 14. Retrieved from http://www.zdnet.com/growing-pc-marketshare-boosts-lenovo-first-quarter-results-7000032614/.

Chen, M. (2012). China market: Over 310, 000 x86 servers shipped in 2Q12, says IDC, November $2 . \quad$ Retrieved from http://www.digitimes.com/news/a20121102PD207.html

-China Daily. (2013). Growth of China X86 server market slows, July 18. Retrieved from http://www.chinadaily.com.cn/business/chinadata/201307/18/content 16794794.htm.

-ChinaTech News. (2014). China Server Market Sales Up 35\% In Q2 2014, September 22. Retrieved from http://www.chinatechnews.com/2014/09/22/20984-chinaserver-market-sales-up-35-in-q2-2014. 
Clover, C. (2014). Lenovo shares fall after lower than expected revenue growth, November 06. Retrieved from http://www.ft.com/intl/cms/s/0/3eb22ff4-65a911e4-a454-00144feabdc0.html\#axzz3SySNnBsc.

-CMIC. (2015). Changes in size of China's x86 server market in 2007. February 18. Retrieved on March. Retrieved from http://www.ccidreport.com/market/article/content/3377/200802/176844.html

Cobb, M. (2015). Implications of IBM selling x86 server business to Lenovo, January 15. Retrieved from http://www.ruggedcloud.com/ibm-sells-x86-lenovo/

Cringely, R.X. (2014). The Decline and Fall of IBM: End of an American Icon. NeRDTV. LLC.

Davis, M. (2014). Morning Read: IBM Offered GlobalFoundries \$1 Billion to Take its Chip Division, August $05 . \quad$ Retrieved from http://www.sevendaysvt.com/OffMessage/archives/2014/08/05/morning-readibm-offered-global-foundries-1-billion-to-take-its-chip-division

Enderle, R. (2015). Can Lenovo Do With x86 Servers What IBM Could Not?, February 03. Retrieved from http://www.tgdaily.com/enterprise/130706-can-lenovo-dowith-x86-servers-what-ibm-could-not\#9XDOFQmYYVLQJlaO.99.

Gagliordi, N. (2014). IBM, Lenovo server deal gets final clearance from US regulators, August 15. Retrieved from http://www.zdnet.com/ibm-lenovo-server-deal-getsfinal-clearance-from-us-regulators7000032675/?s cid=e589\&ttag=e589\&ftag=TREc64629f.

Haber, L. (2014). IBM, Lenovo x86 server deal: Good for partners?, January 23. Retrieved from http://searchitchannel.techtarget.com/news/ 2240213115/IBMLenovo-x86-server-deal-Good-for-partners

Haber, L. (2014). At Lenovo partner conference, company preps partners for IBM, Motorola buys, May $13 . \quad$ Retrieved from http://searchitchannel.techtarget.com/news/2240220624/At-Lenovo-partnerconference-company-preps-partners-for-IBM-Motorola-buys

-HPC Wire. (2014). IDC Reports Worldwide Server Market Revenues, December 04. Retrieved from http://www.hpcwire.com/off-the-wire/idc-reports-worldwideserver-market-revenues/.

-IBM Systems. (2012). IDC Worldwide Quarterly Server Tracker, Q4 and Full Year 2011 Results, February, 29. Retrieved from http://www.ibmsystemsmag.com/mainframe/news/IDC-Worldwide-QuarterlyServer-Tracker

Jiayi, L. (2014). Massive strike at IBM factory in China over Lenovo server deal, March 6. Retrieved from http://www.zdnet.com/cn/massive-strike-at-ibm-factory-inchina-over-lenovo-server-deal-7000027049/.

Kan, (2014). Lenovo set to complete acquisition of IBM x86 server business, September, 29. Retrieved from http://www.pcworld.com/article/2688772/lenovoset-to-complete-acquisition-of-ibm-x86-server-business.html

Kass, D.H. (2014). Lenovo, IBM x86 Server Deal Clears U. S. Regulators-Now What?, August 20. Retrieved from http://thevarguy.com/information-technology-mergerand-acquistion-news/092014/lenovo-ibm-x86-server-deal-clears-us-regulatorsno.

Kerner, S.M. (2014). Third Quarter 2014 Server Revenues Rise, December, 05. Retrieved from http://www.serverwatch.com/server-news/third-quarter-2014server-revenues-rise.html 
Kerner, S.M. (2015). Global Server Market Grew to \$50. 9 Billion in 2014, March 05. Retrieved from http://www.serverwatch.com/server-news/global-server-marketgrew-to-50.9-billion-in-2014.html

Leopold, G. (2015). Lenovo Looks to Duplicate PC Success in Server, Smartphone Markets, February $09 . \quad$ Retrieved from http://electronics360.globalspec.com/article/4988/lenovo-looks-to-duplicate-pcsuccess-in-server-smartphone-markets

Luo, L. (2015). Inspur tops China's booming x86 server market, April 02. Retrieved from http://weidaohang.org/.

Morgan, T.P. (2014). X86 System Sales Grow; Everything Else Shrinks, February, 26. Retrieved from http://www.enterprisetech.com/2014/02/26/x86-system-salesgrow-everything-else-shrinks/.

Morgan, T.P. (2014). Uncle Sam Approves IBM X86 Server Biz Sale To Lenovo, August 18. Retrieved from http://www.enterprisetech.com/2014/08/18/unclesam-approves-ibm-x86-server-biz-sale-lenovo/

Park, M., Yang, D., Nam, C., \& Ha, Y. (2002). Mergers and Acquisitions in the Telecommunications Industry:Myths and Reality. ETRI Journal, 24(1), 56-68. doi:10.4218/etrij.02.0102.0106

Naidu, R. (2015). Inorganic path to growth may be better for cement cos. The Economic Times, New Delhi, April 01, pp12..

-News. (2009). Lenovo to Acquire Mobile Handset Business, November 27. Retrieved from http://www.lenovo.com/news/us/en/2009/11/mobile-handset.html

-News. (2011). Lenovo and NEC form Joint Venture to create Japan's largest PC group, January 2011. Retrieved from http://news.lenovo.com/article display.cfm?article id=1413

-News. (2014). Lenovo to Acquire Motorola Mobility from Google, January 29. Retrieved from http://news.lenovo.com/article_display.cfm? article_id=1768

-News. (2014). Lenovo Completes Acquisition of Motorola Mobility from Google, October 30. Retrieved from http://news.lenovo.com/ article_display.cfm? article_id $=1860$

-News. (2014). Lenovo Q2 revenue lifted by record smart phone shipments, November, 06. Retrieved from http://www.telecompaper.com/news/lenovo-q2revenues-lifted-by-record-smartphone-shipments--1047661.

-News. (2015). Lenovo / IBM career began in servers and storage, January 05. Retrieved from http://www.ibai.com/en/news/2015/01/05//BM-and-LENOVO2012-x86.

Olavsrud, T. (2011). IDC: Worldwide Server Revenues Sluggish but Still Up, December 01. Retrieved from http://www.serverwatch.com/server-news/idcworldwide-server-revenues-sluggish-but-still-up.html

Osborne, C. (2014). IBM, Lenovo server deal potentially scuppered over security, June 26. Retrieved from http://www.zdnet.com/ibm-lenovo-server-deal-potentiallyscuppered-over-security-7000030961/.

Osborne, C. (2014). Lenovo: IBM, Motorola deals to close by 2015, July 02. Retrieved from http://www.cnet.com/uk/news/lenovo-ibm-motorola-deals-to-wrap-up-by2015/.

Osborne, C. (2014). China approves IBM, Lenovo server deal, July 04. Retrieved from http://www.zdnet.com/china-approves-ibm-lenovo-server-deal-7000031251/. 
Patrizio, A. (2014). With its IBM server biz purchase settled, what's next for Lenovo?, August 26. Retrieved from http://www.itworld.com/hardware/433149/its-ibmserver-biz-purchase-settled-whats-next-lenovo

Perez, B. (2015). Lenovo's IBM ties may pave way for enterprise storage acquisition, February $06 . \quad$ Retrieved from http://www.scmp.com/business/companies/article/1421982/next-target-lenovosshopping-spree-may-be-enterprise-storage

Pimentel, B. (2014). Why IBM selling server unit to Lenovo is bad news for H-P, January, 23. Retrieved from http://blogs.marketwatch.com/thetell/2014/01/23/why-ibm-selling-server-unit-tolenovo-is-bad-news-for-h-p/.

Pinaroc, J. (2014). With IBM x86 acquisition done, Lenovo plans to go after BPO firms, December 08. Retrieved from http://newsbytes.ph/2014/12/08/with-ibm-x86acquisition-done-lenovo-plans-to-go-after-bpo-firms/

-PR Newswire. (2008). CCID Consulting: Growth for China's X86 Server Market's to Slow Down, December 03. Retrieved from http://www.prnewswire.com/newsreleases/ccid-consulting-growth-for-chinas-x86-server-markets-to-slow-down65262567.html

-Press Release. (2013). Worldwide server market revenues decline-3. 7\% in the third quarter as weak unix server demand weights on the market according to IDC, December 04. Retrieved from http://www.marketwatch.com/story/worldwideserver-market-revenues-decline-37-in-the-third-quarter-as-weak-unix-serverdemand-weights-on-the-market-according-to-idc-2013-12-04.

-Press Release. (2014). Worldwide Server Market Revenues Decreased -2. 2\% in First Quarter as Volume Server Demand Improves, According to IDC, May 28. Retrieved from http://www.idc.com/getdoc.jsp?containerld=prUS24890714.

-PTI. (2014). Lenovo-IBM server business deal gets CCl green signal, March 24. Retrieved from http://articles.economictimes.indiatimes.com/2014-0324/news/48523789 1 server-market-server-business-lenovo-and-ibm.

Punit, I.S. (2014). Lenovo India to benefit from IBM's 'high margin' server biz, January 24. Retrieved from http://www.business-standard.com/article/companies/lenovoindia-to-benefit-from-ibm-s-high-margin-server-biz-114012301165 1.html

Ranger, S. (2014). IBM, Lenovo and the \$2. 3bn question: Can they hit the jackpot twice?, January 13. Retrieved from http://www.zdnet.com/ibm-lenovo-and-the-23bn-question-can-they-hit-the-jackpot-twice-7000025498/.

Rishi, S. (2014). Post IBM x86 Server Acquisition, Lenovo Foresees Greater Business for Channels, November 12. Retrieved from http://www.channelworld.in/news/ post-ibm-x86-server-acquisition,-lenovo-foresees-greater-business-for-channels-

Ruwitch, J., \& Pomfret, J. (2014). Lenovo reassures IBM staff in China even as strike against deal continues, March 11. Retrieved from http://businesstoday.intoday.in/story/ibm-staff-in-china-on-strike-against-lenovodeal-wage-fears/1/204178.html

Saran, C. (2014). Gartner: IBM suffers and Cisco gains following x86 divestment, December, $03 . \quad$ Retrieved from http://www.computerweekly.com/news/2240235927/Gartber-IBM-suffers-Ciscogains-following-x86-divestment

Saran, C. (2014). Can Lenovo turn around IBM's x86 business and win in the enterprise?, $\quad$ September $29 . \quad$ Retrieved from 
http://www.computerweekly.com/news/2240231679/Can-Lenovo-turn-aroundIBMs-x86-business-and-win-in-the-enterprise

Shah, A. (2014). Lenovo, IBM x86 server strategy gets clarity as acquisition looms, September 08. Retrieved from http://www.pcworld.com/article/2604220/lenovoibm-x86-server-strategy-gets-clarity-as-acquisition-looms.html

Singh, N.P. (2014). Microsoft Acquired Nokia in Unipolar Operating System Market. Independent Journal of Management \& Production, 5(3), 598-622. doi:10.14807/ijmp.v5i3.166

Singh, N.P. (2014). Verizon acquired Vodafone: Analysis of market reaction. Industrija, 42(3), 163-182. doi:10.5937/industrija42-5782

Spooner, J.G., \& Kanellos, M. (2014). IBM sells PC group to Lenovo, December 07. Retrieved on August 08, 2014 from. Retrieved from http://news.cnet.com/IBMsells-PC-group-to-Lenovo/2100-1042 3-5482284.html

-Team Channel World. (2014). India Server Market Sees a Whopping Growth in Q3: Gartner, December, 11. Retrieved from http://www.computerworld.in/news/indiaserver-market-sees-a-whopping-growth-in-q3\%3A-gartner-.

-The Australian. (2014). Jobs cuts not ruled out as Lenovo swallows IBM's x86 server business. October, $07 . \quad$ Retrieved from http://www.theaustralian.com.au/technology/jobs-cuts-not-ruled-out-as-lenovoswallows-ibms-x86-server-business/story-e6frgakx-1227081684268?nk= fd5f5bc37859e68b1230a660d7929315

Thompson, W. (2013). Lenovo Group Limited. Credit Suisse. Retrieved from https://doc.research-and-analytics.csfb.com.

Thompson, W. (2014). Lenovo Group Limited. Credit Suisse,. November 07. Retrieved from https://doc.research-and-analytics.csfb.com.

-Techpowerup. (2012). IDC: Worldwide Server Market Revenues Increase 5. 8\% in 2011, February 2012. Retrieved from http://www.techpowerup.com/161448/idcworldwide-server-market-revenues-increase-5-8-in-2011.html

Turner, P. (2014). Lenovo to Acquire IBM x 86 Server Businesses - A Market Shift with Positive Expectations, Quarter 2. Retrieved from http://datatrend.com/about/trendsetter/trendsetter-q2-2014/lenovo-to-acquireibm-x86-server-business/

VAR, G. (2014). Lenovo Buying IBM x86 Server Business?: 5 Partner Implications, April 19. Retrieved from http://thevarguy.com/business-technology-solutionsales/lenovo-buying-ibm-x86-server-business-5-partner-implications

Whittaker, Z. (2012). Lenovo to buy Brazilian electronics giant CCE, September, 17. Retrieved from http://www.zdnet.com/article/lenovo-to-buy-brazilian-electronicsgiant-ccel.

Whittaker, Z. (2012). Lenovo to acquire software firm Stoneware in cloud-link push, September 18. Retrieved from http://www.zdnet.com/article/lenovo-to-acquiresoftware-firm-stoneware-in-cloud-link-push/.

Wong, W.M. (2014). Investors conference call- Acquisition of IBM's x86 Server Busines. Retrieved from http://www.lenovo.com/ww/lenovo/pdf/Lenovo_Acquisition\%20of\%20IBM\%20Se rver\%20Business PPT 24012014.pdf

Yee, L.C., \& Soh, K. (2011). Lenovo buys German computer seller Medion for $\$ 900$ million, June 01. Retrieved from http://www.reuters.com/article/2011/06/01/uslenovo-idUSTRE75010Y20110601. 
Singh N.P.: Lenovo Acquires IBM's x86 Low-end Server Business

Zuckerman, D. (2012). X86 Intel Server Watch; Intel Series Chips - Part One, March 20. Retrieved from http://serverlift.com/tech-lift/x86-server-watch-intel-e5-2600series-chips/. 